\title{
Co-firing of Biomass with Coal in Pulverized Coal Fired Boilers at Lakvijaya Power Plant: A Case Study
}

\author{
W.D.A.S. Wijayapala and S.R.H. Mudunkotuwa
}

\begin{abstract}
The very first coal fired power plant complex set up in Sri Lanka, the Lakvijaya Power Station, uses pulverized coal power technology. Co-firing of biomass with coal has successfully been demonstrated around the world. There are several co-firing technologies and the pulverized coal fired plants can retrofit the technology very easily.
\end{abstract}

In this study, Gliricidia (Gliricidia Sepium) has been considered as the candidate biomass option which will be mixed with coal to be fired within the same boiler. An extensive analysis was carried out as elaborated in this paper with regard to technical, economical and other concerns that arise when cofiring is introduced to an existing pulverized coal fired installation. Simulations were carried out to verify the outcome of design changes done in the boiler.

When introducing the co-firing technology, there are many aspects to be considered. They are of technical, economical and social nature, and hence can have an impact on the national economy in various ways. As a nation whose future generation plan will be coal dominant, it is vital that Sri Lanka considers the biomass co-firing concept seriously.

Keywords: Coal, Biomass, Co-firing, Pulverized, Boiler

\section{Introduction}

Co-firing is the process of burning two different types of fuels in the same or different boilers to generate power. The main aim is to replace the primary fuel with a secondary fuel to achieve multiple benefits. In the current global context, the two fuels to be used in most of the cases are coal and biomass. Co-firing should not be confused with the combustion of multiple fuels in boilers designed especially for same [1]. The basic difference between such a type of combustion and co-firing is that co-firing is achieved in a boiler originally designed to burn only a specific kind of fuel which is coal in most of the cases. In simple terms, biomass co-firing with coal can be thought of as the process of partially supplementing coal with biomass in coal-fired boilers. The term co-firing ratio is defined as the ratio between coal and biomass blended by weight or energy for combustion [2].

It is noted that co-firing has been implemented using all types of boilers available. Bubbling and circulating fluidized bed boilers and stoker boilers have been utilized, but most of the boilers involved in co-firing are pulverized coal boilers, including tangentially-fired and wall-fired boilers, and cyclone units.
As of 2004, 50\% of the boilers utilized in cofiring were of the pulverized coal fired type [4].

\section{Methodology}

There are many technological options available when coal and biomass are co-fired in pulverised coal fired boilers.

\subsection{Technology Options for Co-firing}

There are three basic technology options as given below which are different to one another [4].

- Direct Co-firing

- Indirect Co-firing

- Parallel Co-firing

\subsubsection{Direct Co-firing}

The basic concept in this method is that both fuels are combusted in the same furnace. This is very commonly used and is proven to be the most economical co-firing configuration.

\footnotetext{
Eng. W.D.A.S. Wijayapala, Int.PEng (SL), CEng, FIE (Sri Lanka), BSc Eng (Hons) (Moratuwa), MEng (Moratuwa), Senior Lecturer, Department of Electrical Engineering, University of Moratuwa.

Eng. S.R.H. Mudunkotuwa, AMIE (Sri Lanka), BSc Eng (Hons), Electrical Engineer (Instrumentation $\mathcal{E}$ Control), Lakvijaya Power Station, Ceylon Electricity Board.
} 
Depending on biomass fuel characteristics, the same or separate mills and burners can be used. In direct co-firing, there are three options which can be employed depending on various characteristics and parameters.

In the first option, biomass and coal are mixed with each other in the fuel handling system and then this blend is fed into the furnace. This is the most straightforward and least expensive option. However, this option can only be accomplished at low percentages of co-firing ratios below 5\%. This option is suitable only for conventional wall or cornerfired boilers [4].

The second option involves the separate milling of biomass, but the pulverized biomass is injected in to the existing pulverized coal pipe work either upstream of the burner or at the burner itself. This involves a higher investment than option one, but will permit higher co-firing ratios [5].

The third option also involves separate biomass milling, but two separate feeding lines are constructed to feed coal and biomass separately in to the boiler. Coal is injected using the original injection system, whereas biomass is injected through dedicated burners in the lower furnace. When compared to other two options of direct cofiring, this option has the highest capital cost.

\subsubsection{Indirect Co-firing}

In this type of co-firing, the solid biomass is gasified separately and the gas so produced is combusted in the furnace of the existing coalfired boiler. This method has a significantly high investment cost [6][7]. However, through this method, a wider range of biomass types can be used since it is the synthesised gas that matters at the entry to the boiler. Also, the Chlorides can be prevented from entering in to the furnace. This is advantageous since Chlorides cause tube corrosion in the boilers. The fly ash from coal burning will be pure as coal is the only solid fuel combusted in the furnace.

\subsubsection{Parallel Co-firing}

In parallel co-firing, biomass is combusted in a separate boiler to produce steam for utilization in the coal-fired power plant. The steam is added to the same cycle. The investment on parallel co-firing installations is higher than that on direct co-firing [4].

\subsection{Selection of the Type of Biomass}

There is a specific set of attributes that the biomass need to have in order to become the successful crop to be grown in large scales to be used for co-firing. They are as follows:

1) High calorific value

2) Ease of moisture removal

3) Favorable growth conditions

4) High growth rate (Easy propagation)

5) Ease of harvesting and transportation

6) Security of supply

7) Chemical composition

\subsubsection{High Calorific Value}

Ina fuel, the most important factor is the calorific value of the biomass type. According to tests carried out on samples of Gliricidia (Table 1), the GCV is found to be in the range $4000 \sim 4300 \mathrm{kcal} / \mathrm{kg}(16.7 \mathrm{MJ} / \mathrm{kg} \sim 18 \mathrm{MJ} / \mathrm{kg})$. When compared with thermal grade coal which carries $26 \mathrm{MJ} / \mathrm{kg}$, it is about a 30\% drop in the calorific value. In order to account for this reduction in calorific value, biomass of about $45 \%$ more in weight has to be added to the furnace for heat compensation. When compared with other biomass fuels available in Sri Lanka, Gliricidia is far ahead in terms of calorific value.

Table 1 - Chemical Analysis of Gliricidia

\begin{tabular}{|l|c|}
\hline \multicolumn{1}{|c|}{ Parameter } & Value \\
\hline Carbon \% & 48.07 \\
\hline Hydrogen \% & 7.34 \\
\hline Oxygen \% & 22.96 \\
\hline Moisture \% & 7.28 \\
\hline Ash \% & 13.63 \\
\hline Sulphur \% & 0.18 \\
\hline Nitrogen \% & 0.54 \\
\hline Gross Calorific Value $(\mathrm{kCal} / \mathrm{kg})$ & 4090 \\
\hline
\end{tabular}

\subsubsection{Ease of Moisture Removal}

Biomass, by its nature, has quite a lot of moisture inside it in raw form. According to sample tests carried out, depending on the crop zone, the amount of biomass in Gliricidia can vary in the range $25 \% \sim 60 \%$. The amount of moisture must be reduced as much as possible to make biomass suitable to be cofired with coal. The drying trials carried out on biomass samples have proven effective ways of moisture removal. Based on these trials, the following conclusions are made.

- Biomass shall be husked and/or split for efficient drying.

- Forced drying improves the rate of moisture removal significantly. 


\subsubsection{Favourable Growth Conditions and Security of Supply}

Environmental conditions, rainfall, temperature, average soil conditions etc., are favourable for the growth of Gliricidia in almost all parts of Sri Lanka. The plantations can be dedicated for Gliricidia or intercropped with coconut, tea or rubber. The growth rate of Gliricidia is very high and can yield 50t/year/ha as a dedicated crop, and $15 \mathrm{t} /$ year/ha as an intercrop.

The security of supply is an extremely important aspect in the long run when it comes to biomass co-firing. The local rural communities have already proven their capacity to supply a promising amount of Gliricidia for the existing small scale boilers. The intercrop agreements between growers and buyers are popular among large scale coconut planters since intercropping of Gliricidia with coconut has many additional benefits as well. Therefore, by promoting these intercrop agreements further, the supply security can be improved significantly.

\subsubsection{Chemical Composition}

The chemical composition of the type of biomass used is extremely important due to two reasons. The biomass combusted in the furnace can pose threats to the lifetime and operation of the boiler due to [8]:

I. Corrosive agents and/or catalysts

II. Ash content

In Gliricidia, two corrosive agents for metal can be identified. They are sulphur (as $S$ and $\mathrm{SO}_{3}$ ) and chlorine (as $\mathrm{Cl}$ ). Sulphur can form Sulphuric acid $\left(\mathrm{H}_{2} \mathrm{SO}_{4}\right)$ in the furnace since moisture and high temperatures are present [9]. Chlorine can form hydrochloric acid $(\mathrm{HCl})$. Both these acids can be detrimental to the boiler internal metallic structure such as water walls, reheater panels, super heaters and other convective panels [10]. The high temperatures will accelerate the acidic corrosive reactions. Tests indicate the presence of about $0.5 \%$ for total Sulphur and $0.98 \%$ for Chlorine on average. The boilers are designed to burn coal having a certain amount of sulphur. For example, the boiler of LPS is designed to burn coal which contains sulphur in the range $0.3 \%$ - $0.8 \%$. When compared to that, the amount of sulphur present in Gliricidia is permissible.

Although the amount of $\mathrm{Cl}$ permissible for boilers is not usually specified, it is found that if the sulphur to chlorine ratio exceeds 5 inside the boiler, the corrosive impact from chlorine gets neutralized due to Sulfation mechanisms inside the boiler [5]. With the addition of sulphur from coal, the total amount of sulphur to chlorine ratio will be very much more than 1:5. Hence, the corrosion from chlorine is minimized and will be controlled naturally.

The ash content is critical since it can cause unnecessary ash deposits on heat transfer surfaces inside the boiler. This will reduce the boiler heat transfer efficiency and can lead to many boiler operational problems. The boiler manufacturers specify a percentage of permissible ash content that can be contained in the fuel that is being combusted in its furnace. For Lakvijaya Power Station, the permissible range is $4.5 \%-16 \%$ [11]. Tests done on samples indicate that the average ash content in Gliricidia is about $13 \%$ which is comparatively low compared with coal. Hence, the total fly ash output from the plant will be lower when replacing high ash coal with low ash biomass. Therefore, it is clear that the chemical composition of biomass is not detrimental to the boiler and other related equipment.

\subsection{Pretreatment Plant Design}

The main function of the pre-treatment plant is to transform the raw form of Gliricidia into a fuel suitable to be sent to the furnace for cofiring with coal. The pre-treatment plant has two main purposes. They are the removal of moisture in biomass and the reduction of particle size of biomass. When it comes to the removal of moisture, the physical attributes of biomass matters to a large degree [12]. It is obvious that the husked biomass removes their moisture faster than the non-husked biomass in raw form.

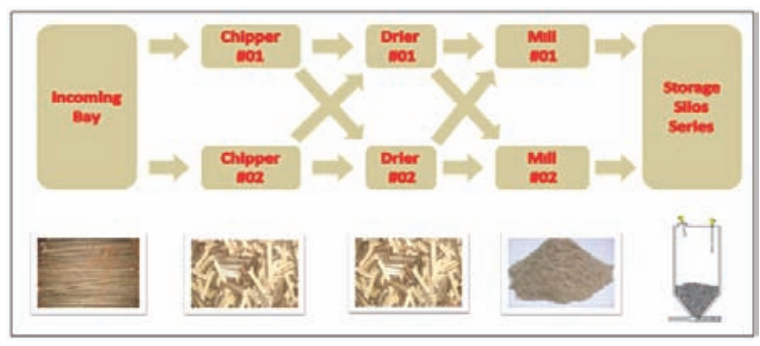

Figure 1 - Pre-treatment Process for Gliricidia

Therefore, the first step in pre-treatment is to alter the physical form of biomass to facilitate the comfortable reduction of moisture. For this, the chipping method is applied on Gliricidia sticks. Disc type wood chippers are used for this purpose. 
Table 2 - Comparison between Direct Co-firing

\begin{tabular}{|c|c|c|c|}
\hline \multicolumn{2}{|r|}{ Direct Co-firing : Option 1} & \multicolumn{2}{|c|}{ Direct Co-firing : Option 2} \\
\hline Advantage & Disadvantages & Advantages & Disadvantage \\
\hline \multirow{4}{*}{$\begin{array}{l}\text { Lowest amount } \\
\text { of investment, } \\
\text { design and } \\
\text { construction } \\
\text { involved }\end{array}$} & $\begin{array}{l}\text { Non-uniformity of the mixture and non- } \\
\text { grind ability }\end{array}$ & $\begin{array}{l}\text { No mill overload } \\
\text { and clogging }\end{array}$ & \multirow{4}{*}{$\begin{array}{l}\text { Line clogging } \\
\text { still exist in } \\
\text { smaller } \\
\text { proportions }\end{array}$} \\
\hline & $\begin{array}{l}\text { Risk of fire due to long term storage of } \\
\text { biomass with coal in bunkers/silos }\end{array}$ & $\begin{array}{l}\text { Less fire risk in silo } \\
\text { storage }\end{array}$ & \\
\hline & High possibility of mill overload & $\begin{array}{l}\text { Line clogging can be } \\
\text { made minimum }\end{array}$ & \\
\hline & $\begin{array}{l}\text { High possibility of mill clogging and } \\
\text { line clogging }\end{array}$ & $\begin{array}{l}\text { Operational } \\
\text { flexibility (ratio } \\
\text { assurance and } \\
\text { variability) }\end{array}$ & \\
\hline
\end{tabular}

After converting in to a suitable size, the biomass pieces are ready to get dried. The chipped sticks are proposed to be dried using a rotary type drier. The dryer will get rid of the majority of the moisture present in the Gliricidia wood chips.

After passing the drier, dried wood chips will be crushed using a crusher to form wood dust since the fuel must be in dust form to be fed into the boiler. After crushing, the wood dust will be stored in a silo to be conveyed into the furnace chamber using conveying air. The process flow design for the pre-treatment plant is shown in Figure 1. An overall rate of $10 \mathrm{t} / \mathrm{h}$ is to be maintained in processing biomass to match the feeding rate of approximately $8 \mathrm{t} / \mathrm{h}$. There are many intermediate conveyers connecting each stage in the pre-treatment process. To increase the process reliability, cross conveying systems are also provided. The path of the process can be selected based on the equipment available at any given time.

\subsection{Selection of the Co-firing Method}

Three main co-firing options were discussed in Section 2.1 which concluded that Option 3 dealing with direct co-firing is not technically suitable for the proposed application. For Option 1 and Option 2 of direct co-firing (in Section 2.1), the advantages and disadvantages can be listed out as shown in Table 2. By comparing the options given in Table 2, the following can be deduced.

Direct co-firing Option 1 has the most number of technical disadvantages when compared to Option 2.These technical disadvantages cannot be overcome easily with the current types of biomass.

The packing patterns of biomass and coal cannot be controlled inside the bunker. Owing to that, the co-firing ratio cannot be controlled and it will vary unpredictably resulting in undesired phenomenon inside the furnace.

The pulverized coal power stations mostly use bowl mills which are designed to grind coal having a HGI (Hargrove Grind ability Index) of 45 - 70. The equivalent index for biomass under normal physical conditions is usually below 20 [13]. Therefore, the co-milling of Gliricidia with coal cannot be done in pulverized coal power stations. If attempted, mill overloading and clogging can occur.

The coal and biomass can be stored in the same bunker. The storage time for a single particle can be $8-9$ hours, depending on the plant dispatch pattern. Coal has a higher calorific value than biomass and both types of fuel have a significant amount of volatile matter. Apart from that, when biomass is handled and stored for several days in silos, they emit methane in small amounts [5]. Due to all these phenomena and prolonged storage with air trapped inside, the probability of a bunker fire occurring increases. Due to temperature increase in the surroundings, the risk gets further high.

Option 2 overcomes the majority of the technical disadvantages found in Option 1. The only technical disadvantage present in Option 2, line clogging, can be considered as a minor one and can be overcome by adopting necessary technical measures. 
Since Gliricidia is pre-treated by other methods, the mill usage is not required. Therefore mill overload and mill clogging will not be present. A dedicated storage is designed for biomass (no mixing with coal). The residence time is reduced to 3 hours by making the silo smaller in order to reduce the fire risk further. Now that the biomass and coal are being prepared separately and injected at two separate places, the fuel ratio between biomass and coal fed to the boiler can be controlled in a real time.

Since the biomass injection is done to existing coal pipelines, biomass can clog lines in small proportions. This can be further minimized by finding the closest possible place to the coal gun to install biomass injectors. This point will be calculated, designed and decided during the final design stage.

Based on the above mentioned technical justifications, it can be concluded that the direct co-firing Option 2 is the most technically viable option for co-firing Gliricidia as biomass in a pulverized coal fired boiler. Among all other options, this method is the easiest to implement and can be retrofitted to the existing system without causing much technical concerns.

\subsection{Final Design}

The overall process schematic for the selected option is shown in Figure 2. The indicated two technical issues shall be addressed and solutions shall be found before finalizing the design.

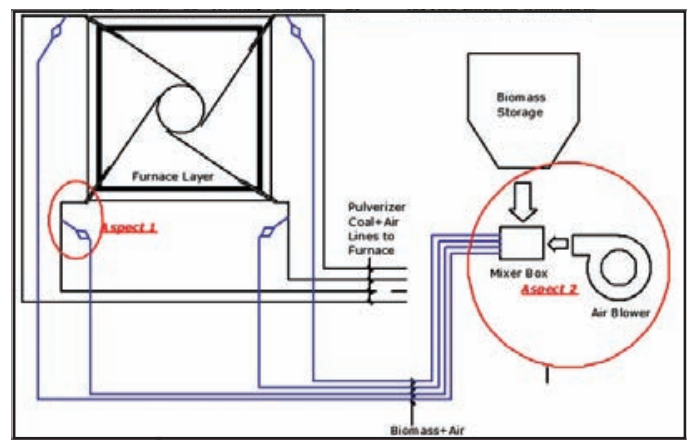

Figure 2 - Overall Process

\subsubsection{Design Aspect 1 : Injection Mechanism}

When injecting biomass in to the existing coal conveying pipeline, there are several parameters to be preserved and to be considered. The ideal objective is to mix coal and biomass to form a uniform mixture which will traverse to the combustion chamber. To design and verify the scenario, it was modelled in 3D space with actual flow parameters and simulated using Solid works 2014 CFD.

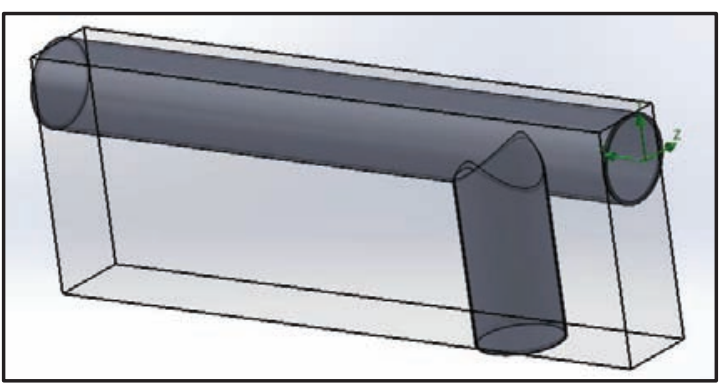

Figure 3 - Solid works Model for Injection of biomass

The results show that the velocities are still comparatively higher and the criteria donot satify the velocity requirement of the design (Figure 3, Figure 4). As per the plots (Figure 5), the velocity after injection reaches an average of $31.2 \mathrm{~m} / \mathrm{s}$ which is about $15 \%$ more than the original incoming velocity of $27 \mathrm{~m} / \mathrm{s}$, and this doesnot satisfy the requirement.

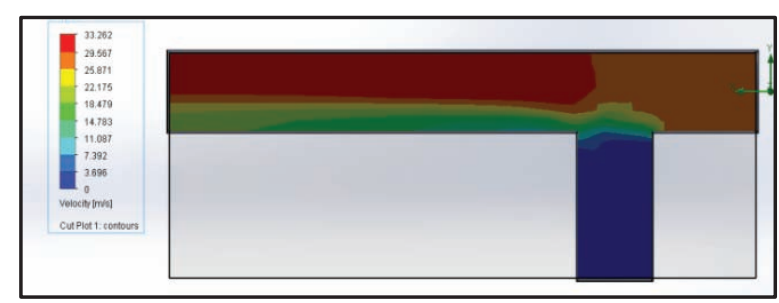

Figure 4 - Velocity Distribution after Simulation

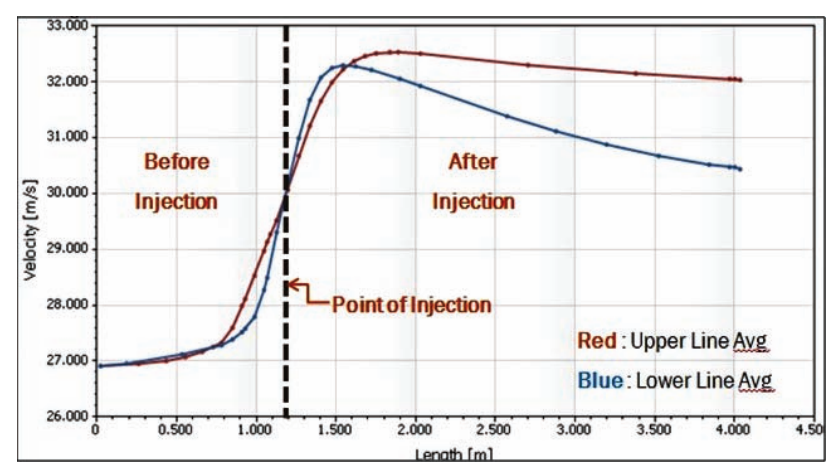

Figure 5 - Velocity Plot Before and after Injection

To overcome the problem of velocity increase, an expander is added to the main pipeline after the point of injection (Figure 6). 


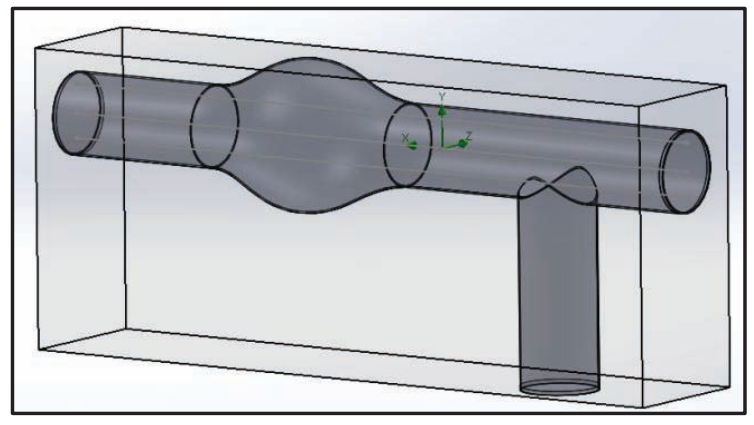

Figure 6 - Modified Model with Expander

After the simulation was done on the modified model, the results showed a considerable improvement when compared to the scenario before (Figure 7). The velocities are now decreased due to the addition of the expander. The velocity plot (Figure 8) shows that the average velocity after injection reaches a value of $26.8 \mathrm{~m} / \mathrm{s}$ while the value before injection is about $26.9 \mathrm{~m} / \mathrm{s}$. The results clearly show that the addition of the expander has led to the achievement of the velocity targets since the velocities before and after injection are now almost the same (Figure 8). Hence, it can be concluded that the injection of biomass in to existing coal pipelines will becomes successful when expanders are introduced.

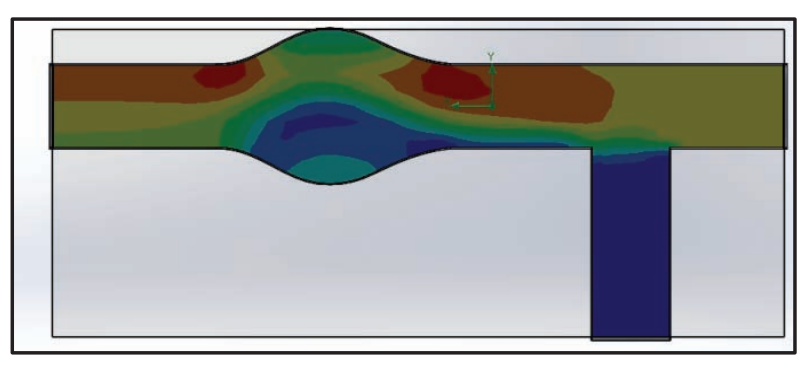

Figure 7 - Simulation Results after Modification

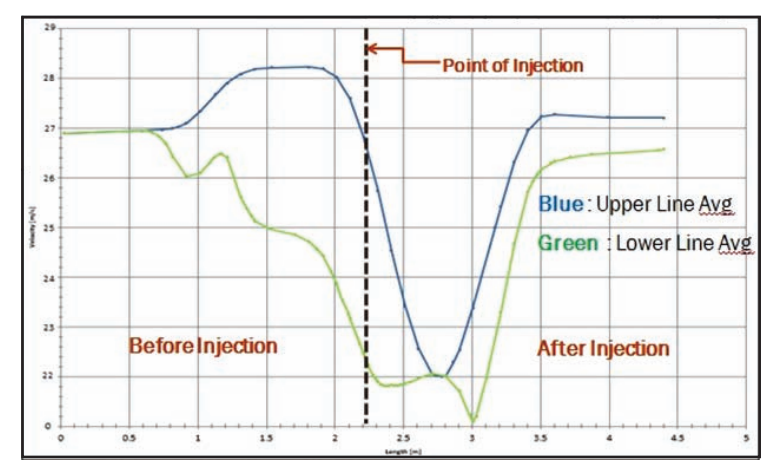

Figure 8 - Velocity Plot after Modification

\subsubsection{Design Aspect 2 : Feed \& Convey}

The biomass conveying system shall be designed to achieve the proper conveying of biomass after mixing with air from the mixer up to the point of injection. The pre-treated biomass is stored in five silos. Each silo will have a feeder which feeds the pre-treated biomass to the conveying air system. The feeder will also measure the biomass feeding rate and will keep it within the operator setting according to the preset co-firing ratio. After the feeder, the biomass is directed to the air manifold using a tree conveying arrangement which will divide the biomass flow in to four equal flows. The four identical biomass flows are to be mixed with the four air flow pipes going to the point of injection (four corners). The tree arrangement surface is subjected to vibration using mini vibrator devices in order to ease the travelling down of biomass through the pipes with the support of gravity.

\section{Economic Evaluation}

Technical evaluation alone is insufficient when it comes to finalizing the decision as to whether it is feasible to go for co-firing biomass. It must be verified financially as well to ensure viability. In making the final decision, the economics behind all installations shall be taken in to account. In other words, the project returns must be verified after all costs and benefits have been taken in to account. The significance in economic evaluation lies among several key related indicators. Some of the economic components are measurable in value and some can be intangible. The cost components are capital cost, O\&M cost, social cost and the environmental cost. The benefit components are returns from fuel savings, social benefits and environmental benefits. The cost of biomass is calculated as shown below.

$$
\begin{gathered}
\text { Total Cost of Biomass }(\mathrm{LKR} / \mathrm{kg})= \\
\text { Purchase price }(\mathrm{LKR} / \mathrm{kg}) \\
+
\end{gathered}
$$

The purchase rate of a unit weight of biomass is the direct fee paid to the grower of biomass. According to the prevailing coconut grower intercrop agreements, the current rate of purchase range from LKR $1.50 / \mathrm{kg}$ to $2.00 / \mathrm{kg}$ based on the amount of moisture ( $>$ or $<30 \%)$. The average can be taken as LKR $1.75 / \mathrm{kg}$ (Year 2014 prices). 
Cost of transportation is calculated assuming the scenario that a 10ton carrier is used to transport biomass from an average distance of $250 \mathrm{~km}$. The value of $250 \mathrm{~km}$ has been taken considering the current and projected distribution of coconut intercrop fields in the country. The destination is selected as the Lakvijaya Coal Power Station at Puttlam. The usual 10t carrier charges are LKR 140/km. Therefore, the total cost of transportation for the average distance is $(140 \times 250)$ LKR $35,000 /$ - The transportation charge per unit weight is $(35,000 / 10,000)$ LKR $3.50 / \mathrm{kg}$ (Year 2014 prices).

Hence, the total cost of biomass when it reaches the plant premises is $(1.75+3.50)$ LKR $5.25 / \mathrm{kg}$.

After considering all capital costs, revenue and expenditure, the simple payback period for the investment was calculated and found to be 2.5 years. After recovering the full investment (within 2.5 years), each year a net profit of about LKR 110 million is possible. Therefore, it is clearly seen that the project is financially viable to be implemented.

\section{Conclusion}

Many countries around the world have already employed biomass co-firing with coal. As a developing country having a tropical climate, Sri Lanka has high potential to try out this technology. The long term generation expansion plan has forecasted many coal power stations to be added to the system within the next 10 years. If proper frameworks and policy decisions in the right direction are made, a massive boom can be brought about among the farming community by employing them in energy plantations.

Since the technical and financial viability have been verified, it is recommended to carryout trials on a pulverized coal fired boiler. Initially, the co-firing should be started with a lower co-firing ratio and the performance of the boiler and generation measured. While monitoring the critical parameters closely, the co-firing ratio has to be increased up to the maximum design value of $5 \%$.

If co-firing ratios of more than $5 \%$ need to be achieved, further studies and modelling will be required.

\section{References}

1. Energy Efficiency Asia Co. (2012) Combustion Technologies [Online]. Available : http://www.energyefficiencyasia.com/com tech

2. Clean Coal Co., (2011). Clean Coal Technology http://www.cleancoal.org/cleantech/cofire

3. Rohan Fernando, "Co-firing High Ratios of Biomass with Coal" CCC/194, IEA Clean Coal Centre, January 2012

4. Loo, S. V., and Koppejan, J., "The Handbook of Biomass Combustion and Cofirirng" London, UK: Earthscan, 2008

5. Fernando, Rohan "Fuels for Biomass Cofiring" CCC/102, IEA Clean Coal Centre, December 2011

6. Isaac Emery and Nathan Moiser, "Emission of Methane from Biomass Feedstocks", GCB Bioenergy, 2014

7. Xiangmei MENG, "Biomass gasification : the understanding of sulfur, tar and char reaction in Fluidized Bed Gasifiers" M.S. thesis, Dept. Mechanical Engineering, Tianjin Univ., China, 2012.

8. Biomass Energy Data Book (2011) [Online] Available: http://cta.ornl.gov/bedb

9. VGB Powertech, "Advantages and Limitations of Biomass Co-combustion in Fossil Fuel Fired Boilers", Powertech Research Centre, USA, 2012

10. Tillman, David, Conn, Richard, Duong, Dao,"Coal Characteristics and Biomass Cofiring in Pulverised Coal Boilers", Electric Power Baltimore, Clinton, NJ, USA 2010

11. China Machinery Engineering Corporation, "Operations Regulations for Pulverised Coal Fired Boilers", Harbin Boiler Company, Harbin, China, 2011

12. Doosan Babcock Energy, "Biomass Firing and co-firing in Large Coal Fired Utility Boilers", W $\mathrm{R}$ Levinstin Coal Research Centre, Leeds, UK, 2010

13. Lei Shang Lars Bach, "Physical \& Chemical Changes in Biomass when Torrefied", World Sustainability Energy Days 2012, Beijing, China 